\title{
基 \\ Morphology of the cardiovascular system in greater rhea (Rhea americana americana Linnaeus, 1758)
}

[Morfologia do sistema cardiovascular de emas (Rhea americana americana Linnaeus, 1758)]

"Scientific Article/Artigo Científico"

\author{
Herson Silva $\operatorname{Costa}^{1}$, Radan Elvis Matias Oliveira ${ }^{1 *}$, Hélio Noberto Araújo Júnior ${ }^{1}$, Ferdinando \\ Vinícius Fernandes Bezerra ${ }^{1}$, Gleidson Benevides Oliveira ${ }^{1}$, Carlos Eduardo Bezerra Moura ${ }^{1}$, \\ Alexsandra Fernandes Pereira ${ }^{2}$, Antônio Chaves Assis Neto ${ }^{3}$, Moacir Franco Oliveira ${ }^{1}$
}

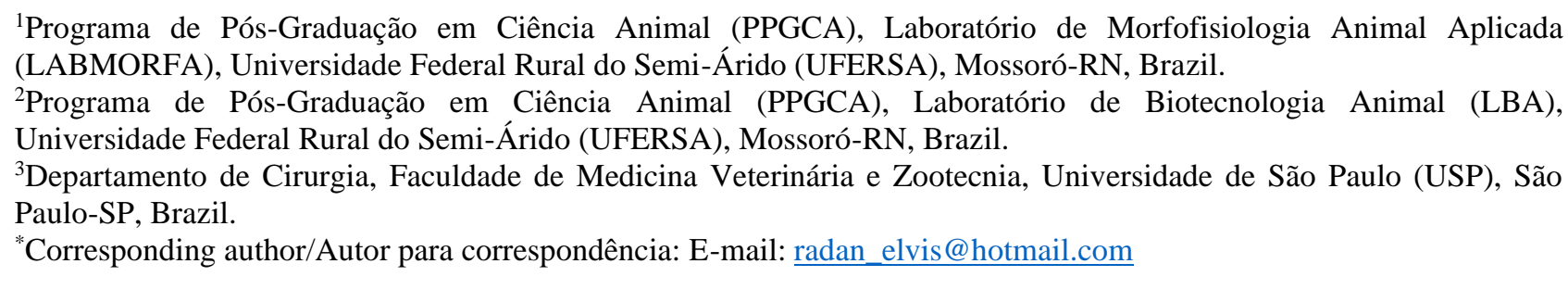

\begin{abstract}
Greater rheas (Rhea americana americana) have been the subject of scientific studies in the various areas of veterinary and biology in order to obtain essential information for their captivity management. The aim of this study was to describe the morphology of the greater rhea heart. The 20 animals were incised in sagittal plane, then fixed in $10 \%$ formaldehyde and dissected after $72 \mathrm{~h}$. In addition, samples from the cardiovascular system were collected, processed for hematoxylin-eosin and Gomori Trichrome Staining. The heart is conical in shape, dark red when fresh and is located between the hepatic lobes. It has two atria and two ventricles, and four valves (left and right atrioventricular, aortic and pulmonary semilunar). The aorta and pulmonary trunk emerge at the heart base, while the ostia of the cranial and caudal vena cava emerged from the right atrium and the right and left pulmonary veins and the left coronary vein from the left atrium. From the aorta artery, the right and left coronary arteries arose, which originated, respectively, the superficial and conal branches and the profuse, left ventricular and superficial branches, being responsible for the irrigation of the heart. Microscopically the heart was constituted by simple pavement epithelium, rich in loose connective tissue. The aorta and pulmonary arteries were composed of the intima, middle and adventitial tunics. Thus, it is concluded that the morphological findings of greater rhea resemble those described for other birds such as ostrich and chicken.
\end{abstract}

Keywords: heart chamber; heart; artery; ratites; valve.

\section{Resumo}

As emas (Rhea americana americana) têm sido objeto de estudos científicos nas diversas áreas da Medicina Veterinária e Biologia, a fim de obter informações essenciais para o manejo em cativeiro. O objetivo deste estudo foi descrever a morfologia do coração da ema. Os 20 animais foram incisados no plano sagital, fixados em formaldeído a 10\% e dissecados após 72 h. Além disso, foram coletadas amostras do sistema cardiovascular, processadas para coloração com hematoxilina-eosina e tricrômico de Gomori. O coração tem forma cônica, vermelho escuro quando fresco e está localizado entre os lobos hepáticos. Possui dois átrios e dois ventrículos e quatro válvulas (atrioventricular esquerda e direita e, semilunares aórtica e pulmonar). A aorta e o tronco pulmonar emergem na base do coração, enquanto os óstios das veias cava cranial e cava caudal emergiram do átrio direito e as veias pulmonares direita e esquerda e a veia coronária esquerda do átrio esquerdo. A partir da artéria aorta surgiram as artérias coronárias direita e esquerda, originando, respectivamente, os ramos superficiais e conais e os ramos profusos, ventriculares esquerdo e superficiais, sendo responsáveis pela irrigação do coração. Microscopicamente, o coração era constituído por epitélio pavimento simples, rico em tecido conjuntivo frouxo. Já as artérias aorta e pulmonar foram constituídas das 
túnicas íntima, média e adventícia. Assim, conclui-se que os achados morfológicos das emas se assemelham aos descritos para outras aves como avestruz e galinha.

Palavras-chave: câmara do coração; coração; artéria; ratitas; válvula.

\section{Introduction}

Greater rheas (Rhea americana americana) are birds belonging to the Rheidae family and are part of the ratite group due to their inability to fly (Sick, 1997). It is a species found in Brazil, specifically in the Northeast, Midwest and Southeast, and are sociable animals which can reach up to 40 years of age. In addition to the economic importance that this species may have for the population, it has aroused scientific interest, aiming to obtain information which enhances its status as a domesticated animal (Belton and Dunning, 1993).

The knowledge of the biology and ecology of greater rheas is being expanded, but information about the morphology of the cardiovascular system is still scarce. In the literature, there are studies describing arterial vascularization in the cloacal bursa (Oliveira et al., 2016), the collateral branches of the aortic arch (Costa et al., 2017), and the vascularization of the brain base (Costa et al., 2018). However, information about the morphology of the heart in this species is still scarce, aspects that become important from the point of view of knowledge of its morphology.

Detailed knowledge of the cardiovascular system is an important prerequisite when interpreting experimental data in research, as well as in the diagnosis of cardiovascular disease using imaging techniques such as Doppler echocardiography and contrast radiography (Bortolini et al., 2013; Cabral et al., 2010). Such descriptions may also be useful in toxicological studies, as numerous chemical products, including some drugs, can produce cardiovascular system malformations during embryonic development (Monnereau et al., 2005). Thus, detailed anatomical descriptions of thegreater rhea's cardiovascular system are indispensable for professionals.

Thus, considering that these birds have economic and scientific importance and there is a lack of data in the literature about their cardiac morphology, the objective was to describe the morphology of the heart in order to identify the cardiac chambers, atrioventricular valves, aortic and pulmonary semilunar valves, and also the coronary arteries, thereby contributing with relevant information on their biology, as well as producing useful information for developing clinical, surgical and consequently health procedures for the species.

\section{Material and Methods}

The 20 young animals (ranging from 1 to 3 months) and adult (18 months) greater rheas (10 females and 10 males) were used in this study who had died from natural causes and were frozen in a freezer at the CEMAS (Wild Animals Multiplication Center) of the UFERSA (Federal Rural University Semi-Árido), Mossoró-RN, which is a scientific breeding site registered with IBAMA (Brazilian Institute of Environment and Renewable Natural Resources) (Registration n. 1478912).

The animals were thawed and incised in the sagittal plane in the craniocaudal direction to expose the heart, then fixed in $10 \%$ aqueous formaldehyde solution. Next, dissections and analysis of the structures began after $72 \mathrm{~h}$. Photographic images were obtained from the samples (SONY DSC-W570 16.1 MP Digital Camera) for illustration of the results (Faria and Melo, 2007; Silva et al., 2012).

The five young animals (three months old, three males, and two females) who died due to natural causes were used for microscopic analysis. Cardiovascular samples were collected and added to vials containing $0.1 \%$ sodium phosphate buffered with $4 \%$ paraformaldehyde solution, $\mathrm{pH}$ 7.4 , at $4^{\circ} \mathrm{C}$ for $48 \mathrm{~h}$. After fixation was completed, the material was submitted to the inclusion battery to obtain the blocks and produce $5 \mu \mathrm{m}$ microtome sections (LEICA RM2125RT). Soon after, the slides were stained according to the hematoxylineosin (HE) technique for cellular disclosure, as well as Gomori Trichrome Staining to differentiate epithelium, connective tissue and muscle tissue. The material was subsequently analyzed and photographed under a light microscope (LEICA DM 500 HD) with a camera attached to a monitor (LEICA ICC50W). The employed methodology was based on histological techniques recommended by Tolosa et al. (2003) with adaptations, depending on the nature of the material. 
The study was based on the nomenclature adopted by Nomina Anatomica Avium (Baumel, 1993) for denominating the identified structures and were compared with studies performed in other birds, as well as mammals and reptiles, with the results being expressed based on descriptive anatomy.

\section{Results}

The heart of the greater rhea is conical in shape, dark red in color when fresh, or pale or whitish after fixation. It is located between the hepatic lobes in the cranio-ventral region of the thorax, perpendicular to the longitudinal axis of the body (Figure 1).

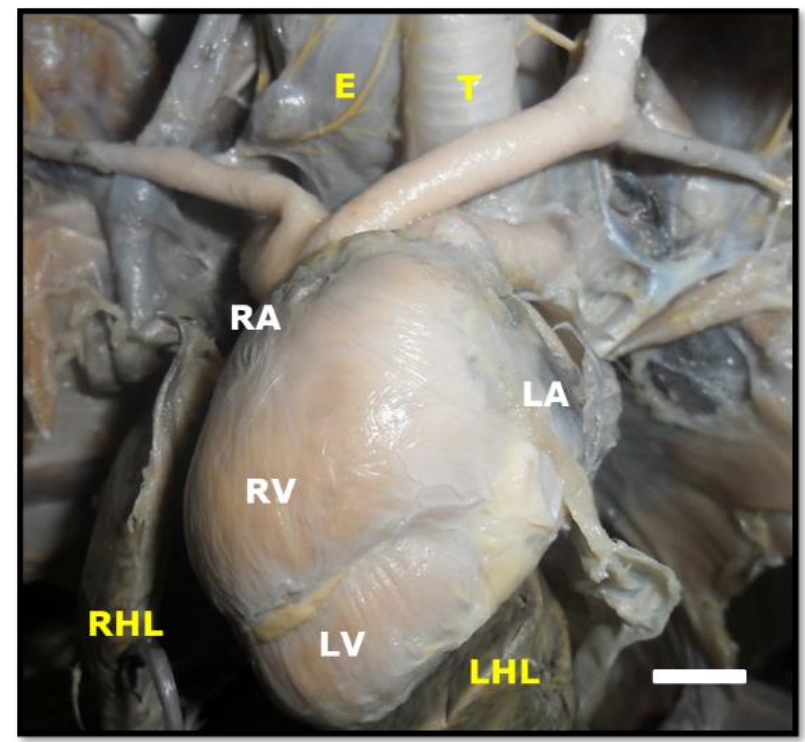

Figure 1. Topography and morphology of the heart in young greater rhea (Rhea americana americana), ventral view. The right atrium (RA); left atrium (LA); right ventricle (RV); left ventricle (LV); right hepatic lobe (RHL); left hepatic lobe (LHL); esophagus (E); trachea $(\mathrm{T})$. Bar $=1 \mathrm{~cm}$.

The heart has four chambers internally, corresponding to two atria and two ventricles, which connect in the right atrioventricular direction through the right atrioventricular valve (Figure 2A), and in the left atrioventricular direction through the left atrioventricular valve (Figure 2B). The pulmonary (semilunar) valve in the pulmonary trunk from the right ventricle (Figure 2C) and the aortic valve (semilunar) in the aorta from the left ventricle (Figure 2D) were also verified. Microscopically, the atria and ventricles consisted of a simple pavement epithelium, loose connective tissue and cardiac striated muscle tissue, with disorganized tissue configuration being observed in the right atrium, as well as the epicardium, consisting of dense connective tissue, externally lining the cardiac chamber (Figure 3 ).

The right and left atria are separated by the interatrial septum, and the right and left ventricles by the interventricular septum (Figure 4). The atrial cavities are smooth, except for the auricles, in which the pectinous muscles formed by muscular protrusions are present (Figure 5). Some structures were found microscopically when detailing the interatrial septum such as collagenrich connective tissue, muscle fibers and hyaline cartilage, both well-delimited structures (Figure $6)$.

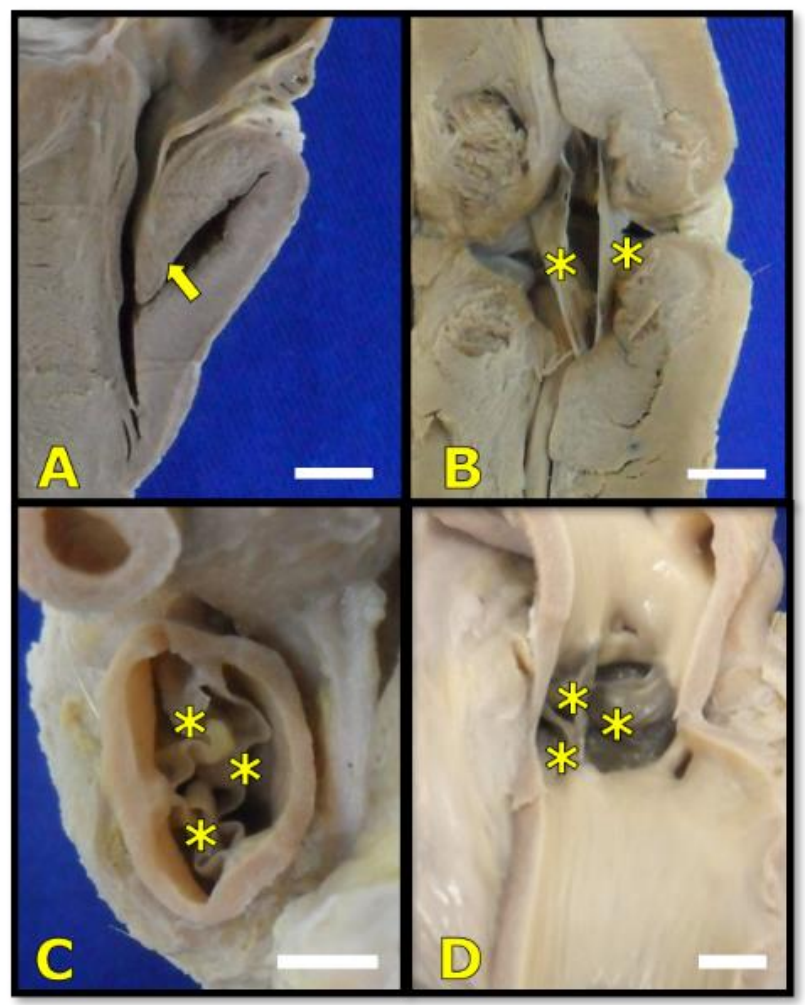

Figure 2. Heart valve macroscopy of adult greater rhea (Rhea americana americana). In $\mathrm{A}$, the right ventricle (in longitudinal section) is verified, showing the right atrioventricular valve as a myocardial muscle fold (arrow). In B, the left ventricle region (in cross-section) is observed, showing the left atrioventricular valve as being a fibrous bicuspid (*). In C, the pulmonary trunk is verified (in crosssection), observing the pulmonary semilunar valve (*). D shows the aorta artery (in longitudinal section), where the aortic semilunar valve is located (*). Bar $=1 \mathrm{~cm}$.

The heart externally presents venous ostia, cranial and caudal cavities in the right atrium, while the right and left pulmonary venous ostia and left coronary vein are in the left atrium (Figure 7A). 
The aorta and the pulmonary trunk emerge from the heart base (Figure 7B), the right (Figure 8A) and left (Figure 8B) coronary arteries appear from the aorta, and the right coronary artery emits superficial and conal branches (Figure 8A), while the left coronary artery emits the profuse, left ventricular and superficial branches (Figure 8B). The internal ostia of the right and left coronary arteries were observed through a longitudinal section in the aorta (Figure 8C).

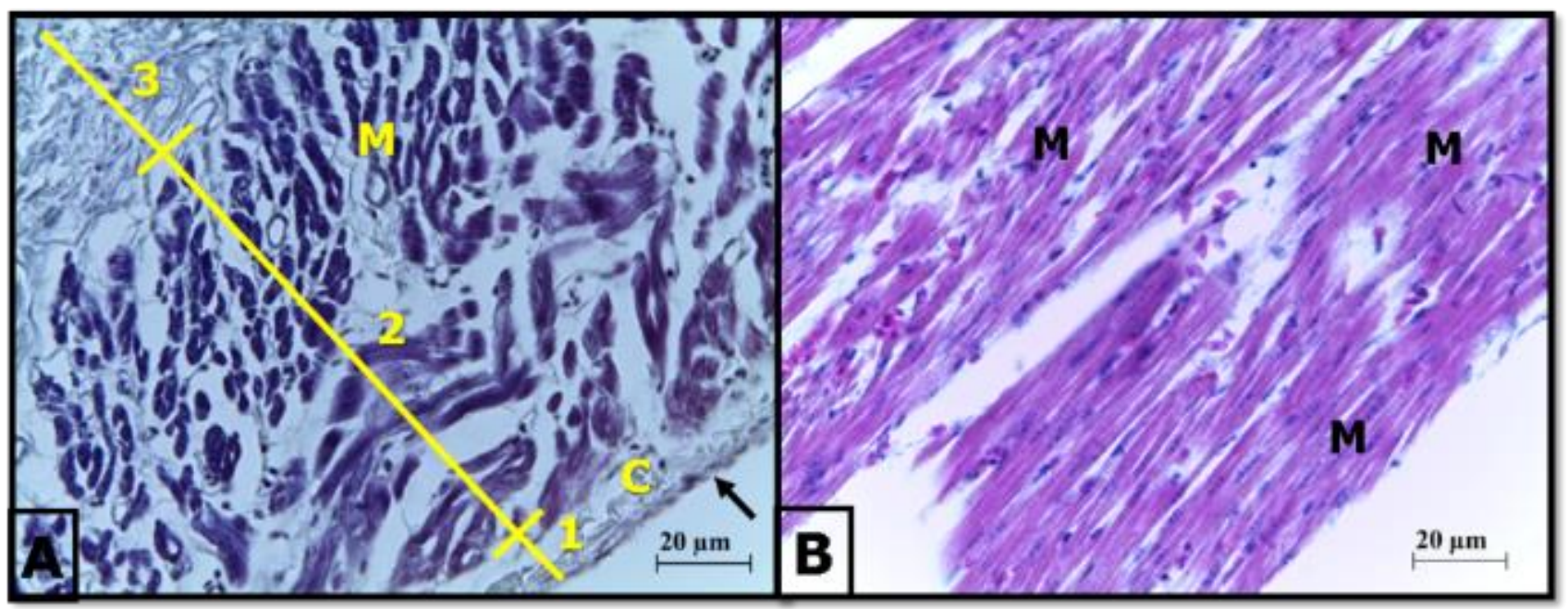

Figure 3. Vascular photomicrography of greater rhea (Rhea americana americana). In A, the right atrium, organized in three layers, endocardium (1); myocardium (2); and epicardium (3), where a simple paved epithelium is observed (arrow); loose connective tissue (C); muscle layer (M). Gomori Trichrome Staining. In B, the left ventricle showing striated cardiac muscle fibers (M). Hematoxylin-eosin staining (HE).

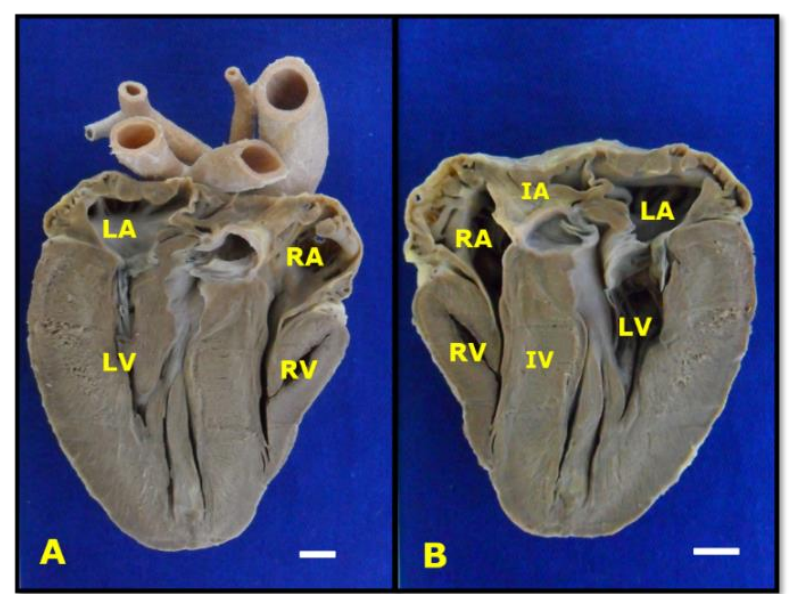

Figure 4. Internal photomacroscopy of the adult greater rhea (Rhea americana americana) heart, longitudinal section view. In $\mathrm{A}$, the internal chambers are verified, showing the right atrium (RA); left atrium (LA); right ventricle $(\mathrm{RV})$; left ventricle $(\mathrm{LV})$. In $\mathrm{B}$, there are the internal heart structures, where the right atrium (RA) is observed; left atrium (LA); right ventricle (RV); left ventricle (LV); interatrial septum (IA); interventricular septum (IV). Bar= $1 \mathrm{~cm}$.

Regarding microscopy, it was observed that the aorta and pulmonary arteries were welldefined, intima, middle and adventitial tunics, and the intima portion of the aorta was quite developed, while the middle pulmonary trunk tunic deserved greater emphasis (Figure 9).

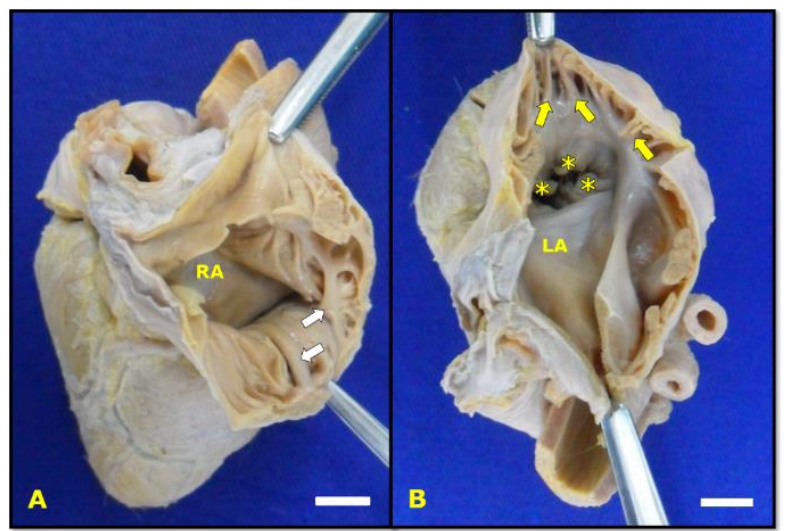

Figure 5. Internal macroscopy of the atria of the adult greater rhea (Rhea americana americana) heart. In $\mathrm{A}$, there is the right atrium (RA); pectinus muscles (arrow). In $\mathrm{B}$, the left atrium (LA) is observed; left atrioventricular valve $(*)$; pectinus muscles (arrow). Bar= $1 \mathrm{~cm}$.

\section{Discussion}

Morphologically, the greater rhea heart had a conical shape, red in color when fresh, and whitish or pale after fixation, being located between the hepatic lobes and perpendicular to the longitudinal axis of the body, similar to that 
described by Dyce et al. (2019) referring to chicken (Gallus gallus domesticus), and by Guimarães et al. (2011) in studies conducted with ostriches. In contrast, the heart base in wild mammals such as anteater (Pinheiro et al., 2014), is in contact with the medial faces of the lungs and the apex in contact with the sternum. While in humans (Weinhaus and Roberts, 2005), the heart is located between the lungs, being topographically dorsal to the sternum, ventral to the spine, and anterior to the diaphragm. It is important to note that both greater rhea and humans have bipedal height, however, rheas are devoid of a diaphragm, which explains the direct relationship of the heart to the liver.

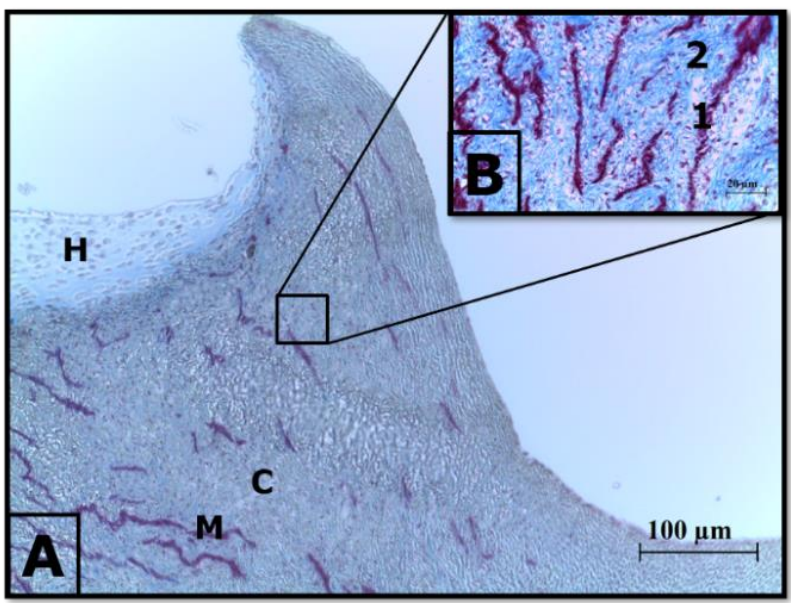

Figure 6. Photomicrograph of the greater rhea (Rhea americana americana) heart. In $\mathrm{A}$, the interatrial septum, showing hyaline cartilage $(\mathrm{H})$; connective tissue $(\mathrm{C})$; muscle fibers (M). In B, detail of the interaction of muscle fibers (1) and connective tissue (2). Gomori Trichrome Staining.

Four cardiac chambers were observed internally in the heart of these animals, corresponding to two atria and two ventricles, as described by Soares et al. (2010) in studies with ostriches, as well as in domestic animals (Dyce et al., 2019), and in wild mammals such as guinea pigs (Barbino et al., 2011) and anteaters (Pinheiro et al., 2014). This has similarly been reported in humans (Weinhaus and Roberts, 2005), however, differently from what occurs in reptiles such as snakes, lizards and turtles (Kik and Mitchell, 2005; Mitchell, 2009), in which it was identified that the interventricular septum is incomplete, resulting in the existence of three cardiac chambers. These similarities between birds, mammals and marsh alligators are directly related to the taxonomic classification of the cardiovascular system, characterized as being double type (when there is separation of blood into two parts: venous blood and arterial blood), closed (when the blood passes inside veins and arteries) and full (when arterial blood does not mix with venous).

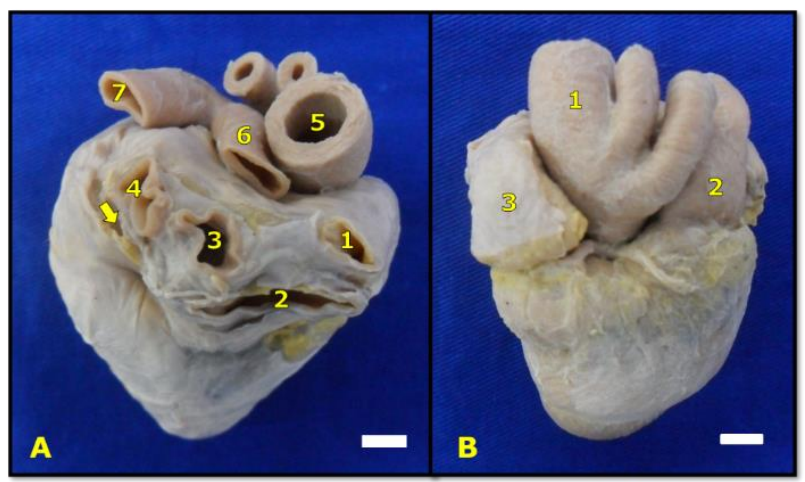

Figure 7. External photomacroscopy of the adult greater rhea (Rhea americana americana) heart. In $\mathrm{A}$, the atrial face, the ostia are equivalent to the vessels of the heart base, showing the ostium of the cranial vena cava (1); caudal vena cava ostium (2); right pulmonary vein ostium (3); left pulmonary vein ostium (4); left coronary vein ostium (arrow); aorta artery (5); right pulmonary artery (6); left pulmonary artery (7). In B, the auricular face, the aorta is observed at the heart base (1); pulmonary trunk (2); right auricle (3). Bar $=1 \mathrm{~cm}$.

In greater rheas, the right atrioventricular valve presented as a muscular fold from the ventricular wall, while the left atrioventricular valve presented as a fibrous bicuspid, as described for chickens (Baumel, 1993), domestic mammals (Dyce et al., 2019) and ostriches (Soares et al., 2010). Regarding the pulmonary trunk and aortic valves, it was evidenced that these are semilunar (pulmonary and aortic), both broad, deep and elastic tricuspids in rheas, which in turn perform the function of avoiding reflux of blood from the arteries to the heart. These findings corroborate studies by Soares et al. (2010) in ostriches.

For the vessels of the heart base in the studied specimens, it was found that the aorta artery and the pulmonary trunk appeared externally, as well as the venous ostia (cranial and caudal cavities, left coronary and right and left pulmonary arteries). In studies with ostriches, Tadjalli et al. (2009) describe the presence of two ostia, represented by the right cranial vena cava and left cranial vena cava, aspects which differ from the findings obtained for rheas. 
The greater rhea aorta artery was microscopically characterized by a welldeveloped, middle and adventitial intima tunic. Our findings were in agreement with the study developed by Guimarães et al. (2018) in Magellanic penguins (Spheniscus magellanicus), which described having an undeveloped intima tunic. This characteristic may be explained by the bird's size, as it a larger rhea and thus requiring a larger vessel to perform its function.

Regarding the heart irrigation, it was evident in the rhea that this function was performed by the right and left coronary arteries which arose from the aorta, and the right coronary artery ran between the right auricle and the pulmonary trunk, while the left coronary artery transited intimately between the pulmonary trunk and the left auricle, similar to that found in the ostrich (Bezuidenhout, 1984), domestic geese (Santos et al., 2006), and domestic mammals (Dyce et al., 2019). It was also observed that the right coronary artery emitted the superficial and conal branches, while the left coronary artery gave rise to the profuse, left ventricular and superficial branches; this pattern diverged from that described by Soares et al. (2010) in ostriches, who reported that the right coronary artery originated the right circumflex branch, while the left coronary artery branched into the paraconal interventricular branch and the left circumflex branch.

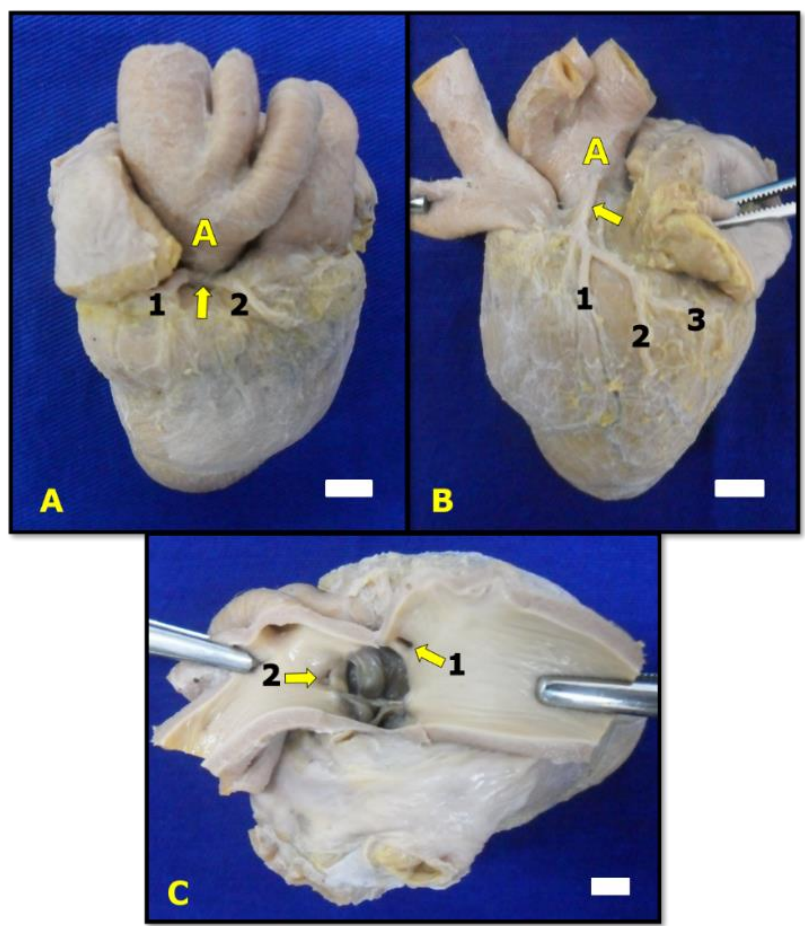

Figure 8. Macroscopy of the right and left coronary arteries of the adult greater rhea (Rhea americana americana). In $\mathrm{A}$, the auricular face, the origin and branch of the right coronary artery are verified (arrow); superficial branch (1); conal branch (2) and aorta artery (A). In B, left lateral view, we can see the origin and branch of the left coronary artery (arrow); profuse branch (1); left ventricular branch (2); superficial branch (3) and aorta artery (A). In C, we can see the internal ostium of the right coronary artery (1) and the internal ostium of the left coronary artery (2) from the longitudinal section of the aorta. Bar $=1 \mathrm{~cm}$.

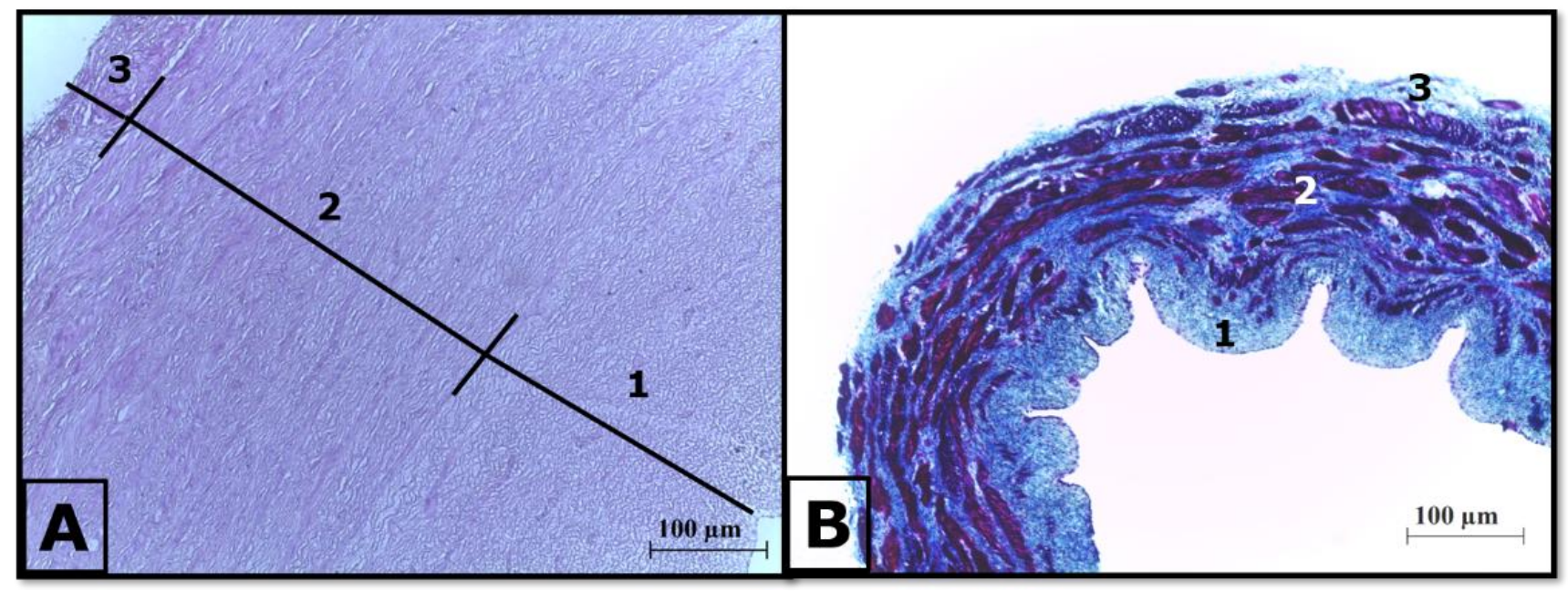

Figure 9. Photomicrography of the main arteries of the greater rhea (Rhea americana americana) heart. In A, the aortic artery stained with HE, with the three tunics, the intima (1); middle (2); adventitia (3). In B, the pulmonary artery showing the tunics, intima (1); middle (2); adventitia (3). Gomori Trichrome Staining. 


\section{Conclusion}

Thus, it is concluded that the morphological findings of greater rhea (Rhea americana americana) are similar to those described for other birds, such as the ostrich, which also belongs to the ratites group, and chichens. The morphological similarity presented in this study can provide valuable information from an evolutionary point of view, as well as for the development of clinical and surgical procedures.

\section{Conflict of Interest}

The authors declare that they have no conflict of interest.

\section{Ethics Committee}

The experiment was approved with authorisation from the Ethics Committee on Animal Use of the Federal Rural University of the Semi-Árido (License No. 09/2015, Process No. 23091.004968/2015-23).

\section{References}

Barbino, M.T.; Oliveira, C.M.; Fonseca, E.T.; Favaron, P.O.; Rodrigues, M.N.; Miglino, M.A. Anatomy of the heart of Guinea pig fetuses in late gestation (Cavia porcellus Linnaeus, 1758). Biotemas, 24(3): 91-96, 2011.

Baumel, J.J. Handbook of avian anatomy: Nomina Anatomica Avium. $2^{\text {nd }}$ ed. Cambridge: Nuttall Ornithological Club, 1993.779p.

Belton, W.; Dunning, J. Aves silvestres do Rio Grande do Sul. $3^{\text {a }}$ ed. Porto Alegre: Fundação Zoobotânica do Rio Grande do Sul, 1993. $174 p$.

Bezuidenhout, A.J. The coronary circulation of the heart of the ostrich (Struthio camelus). Journal of Anatomy, 138(3): 385-397, 1984.

Bortolini, Z.; Matayoshi, P.M.; Santos, R.V.; Doiche, D.P.; Machado, V.M.V.; Teixeira, C.R.; Vulcano, L.C. Casuística dos exames de diagnóstico por imagem na medicina de animais selvagens - 2009 a 2010. Arquivo Brasileiro de Medicina Veterinária e Zootecnia, 65(4), 1247-1252, 2013.

Cabral, R.R.; Ciasca, B.D.; Oliveira, V.M.C.; Vaz-Curado, A.P.; Larsson, M.H.M.A. Valores da pressão arterial em cães pelos métodos oscilométrico e Doppler vascular.
Arquivo Brasileiro de Medicina

Veterinária e Zootecnia, 62(1), 64-71, 2010.

Costa, H.S.; Oliveira, R.E.M.; Bezerra, F.V.F.; Câmara, F.V.; Oliveira, G.B.; Moura, C.E.B.; Oliveira, M.F. Collateral branches of the aortic arch in the greater rhea (Rhea americana americana Linnaeus, 1758). Bioscience Journal, 33(2): 354-363, 2017.

Costa, H.S.; Araújo Júnior, H.N.; Bezerra, F.V.F.; Rebouças, C.E.V.; Menezes, D.J.A.; Moura, C.E.B.; Oliveira, M.F. Anatomia macroscópica e vascularização do encéfalo de emas (Rhea americana americana). Acta Scientiae Veterinariae, 46(1539): 1-8, 2018.

Dyce, K.M.; Sack, M.O.; Wensing, C.J.G. Tratado de anatomia veterinária. $5^{\text {a }}$ ed. Rio de Janeiro: GEN Guanabara Koogan, 2019. 872p.

Faria, M.D.; Melo, A.P.F. Topografia, morfologia e irrigação do Baço em Trachemys scripta elegans (WIED, 1838). Brazilian Journal of Veterinary Research and Animal Science, 44(3): 167-173, 2007.

Guimarães, D.F.; Carvalho, A.P.M.; Ywasak, J.; Neves, I.C.D.; Rodrigues, A.B.F.; Silveira, L.S. Morphology of heart and vessels of the cardiac base in Magellanic penguin (Spheniscus magellanicus). Arquivo Brasileiro de Medicina Veterinária e Zootecnia, 70(4): 1195-1202, 2018.

Guimarães, D.F.; Rodrigues, A.B.F.; Silveira, L.S.; Almeida, A.T.S.; Souza, G.B.B.; Silva, M.P.S.S. Morphometric study of the heart of ostrich (Struthio camelus). PUBVET, 5(11): 1-10, 2011.

Kik, M.J.L.; Mitchell, M.A. Reptile cardiology: a review of anatomy and physiology, diagnostic approaches, and clinical disease. Seminars in Avian and Exotic Pet Medicine, 14(1): 52-60, 2005.

Mitchell, M.A. Reptile cardiology. Veterinary Clinics of North America: Exotic Animal Practice, 12(1): 65-79, 2009.

Monnereau, L.; Carretero, A.; Berges, S.; Navarro, M.; Leonard, M.; Lyazrhi, F.; Sautet, J.; Ruberte, J. Morphometric study of the aortic arch and its major branches in rat fetuses on the $21^{\text {st }}$ day of gestation. Anatomy and Embryology, 209(1): 357-369, 2005.

Oliveira, R.E.M.; Oliveira, G.B; Bezerra, F.V.F.; Câmara, F.V.; Costa, H.S.; Silva, A.V.N.; Oliveira, M.F. Arterial vascularization of the cloacal bursa of greater rhea (Rhea 
americana americana Linnaeus, 1758). Bioscience Journal, 32(3):691-698, 2016.

Pinheiro, G.S.; Branco, E.; Pereira, L.C.; Lima, A.R. Morphology, topography and irrigation of the heart of Tamandua tetradactyla. Arquivo Brasileiro de Medicina Veterinária e Zootecnia, 66(4): 1105-1111, 2014.

Santos, T.C.; Pereira, C.C.H.; Bombonato, P.P.; Monteiro Filho, L.P.C. Origin and ramification of the brachiocephalic trunk and subclavian artery in domestic goose (Anser domestica). Brazilian Journal of Veterinary Research and Animal Science, 43(3): 296-301, 2006.

Sick, H. Ordem Rheiformes - emas: família Rheidae. In: Sick, H. Ornitologia brasileira. Rio de Janeiro: Nova Fronteira, 1997. p.168171.

Silva, B.X.; Roza, M.S.; Babinski, M.A.; Palhano, H.B.; Scherer, P.O.; Figueiredo, M.A. Ramos principais da artéria celíaca no gato doméstico: estudo aplicado à pesquisa experimental e à prática cirúrgica. Revista Brasileira de Ciência Veterinária, 19(3): 133-138, 2012.

Soares, G.L.; Oliveira, D.; Artoni, S.M.B. Aspects of the ostrich heart anatomy. Ars Veterinaria, 26(1): 38-42, 2010.

Tadjalli, M.; Ghazi, S.R.; Parto, P. Gross anatomy of the heart in Ostrich (Struthio camelus). Iranian Journal of Veterinary Research, 10(1): 21-27, 2009.

Tolosa, E.M.C.; Rodrigues, C.J.; Behmer, A.O.; Freitas Neto, A.G. Manual de técnicas para histologia normal e patológica. $2^{\mathrm{a}}$ ed. São Paulo: Manole, 2013. 341p.

Weinhaus, A.J.; Roberts, K.P. Anatomy of the human heart. In: Iaizzo, P.A. Handbook of cardiac anatomy, physiology, and devices. Totowa: Humana Press, 2005. p.51-79. 